University of Nebraska - Lincoln

DigitalCommons@University of Nebraska - Lincoln

August 2007

\title{
Isotype-specific antibody responses against Escherichia coli 0157:H7 locus of enterocyte effacement proteins in adult beef cattle following experimental infection
}

\author{
G. Bretschneider \\ University of Nebraska - Lincoln \\ E. M. Berberov \\ University of Nebraska - Lincoln \\ Rodney A. Moxley \\ University of Nebraska - Lincoln, rmoxley1@unl.edu
}

Follow this and additional works at: https://digitalcommons.unl.edu/vetscipapers

Part of the Veterinary Medicine Commons

Bretschneider, G.; Berberov, E. M.; and Moxley, Rodney A., "Isotype-specific antibody responses against Escherichia coli 0157:H7 locus of enterocyte effacement proteins in adult beef cattle following experimental infection" (2007). Papers in Veterinary and Biomedical Science. 76.

https://digitalcommons.unl.edu/vetscipapers/76

This Article is brought to you for free and open access by the Veterinary and Biomedical Sciences, Department of at DigitalCommons@University of Nebraska - Lincoln. It has been accepted for inclusion in Papers in Veterinary and Biomedical Science by an authorized administrator of DigitalCommons@University of Nebraska - Lincoln. 
Published in Veterinary Immunology and Immunopathology 118:3-4 (August 15, 2007), pp. 229-238.

DOI: 10.1016/j.vetimm.2007.06.005 Copyright (C) 2007 Elsevier B.V. Used by permission.

Submitted February 23, 2007; revised May 15, 2007; accepted June 8, 2007; published online June 15, 2007.

\title{
Isotype-specific antibody responses against Escherichia coli O157:H7 locus of enterocyte effacement proteins in adult beef cattle following experimental infection
}

\author{
G. Bretschneider, E.M. Berberov*, and R.A. Moxley† \\ Department of Veterinary and Biomedical Sciences, University of Nebraska-Lincoln, \\ Fair Street and East Campus Loop, Lincoln, NE 68583-0905, USA \\ * Present address: Vaccine and Infectious Disease Organization, University of Saskatchewan, \\ 120 Veterinary Road, Saskatoon, Sask. S7N 5E3, Canada. \\ † Corresponding author. Tel.: +1 402472 8460; fax: +1 4024729690.
}

\begin{abstract}
Escherichia coli $\mathrm{O} 157: \mathrm{H} 7$ is an important food-borne pathogen and cause of hemorrhagic colitis and hemolytic uremic syndrome in humans. Cattle are an important reservoir of E. coli O157:H7, in which the organism colonizes the intestinal tract and is shed in the feces. Vaccination of cattle has significant potential as a pre-harvest intervention strategy for E. coli O157:H7; however, basic information about the bovine immune responses to important bacterial colonization factors resulting from infection has not been reported. The serum and fecal IgG and IgA antibody responses of adult cattle to E. coli O157:H7 intimin, translocated intimin receptor (Tir), E. coli-secreted proteins (Esp)A, EspB and O157 lipopolysaccharide (LPS) in response to infection were determined. All animals were seropositive for all five antigens prior to inoculation, with antibody titers to EspB and O157 LPS significantly higher $(P<0.05)$ than those to Tir, intimin and EspA. After inoculation, the cattle became colonized and developed significant increases in their serum antibody titers to intimin, Tir, EspB, EspA and O157 LPS $(P<0.05)$; however, by 42 days post-inoculation the titers to all except EspB were on the decline. In contrast, pre- and post-inoculation fecal IgG and IgA antibodies to these same antigens were not detected $(<1: 5)$. These results indicate that cattle respond serologically to $E$. coli O157:H7 type III secreted proteins, intimin and O157 LPS during the course of infection and the response is correlated with the extent of fecal shedding.
\end{abstract}

Keywords: Escherichia coli O157:H7, Cattle, Type III secreted proteins, Locus of enterocyte effacement, Antibodies, Humoral immunity

\section{INTRODUCTION}

Escherichia coli O157:H7 is an important food-borne, zoonotic pathogen that causes hemorrhagic colitis and hemolytic uremic syndrome (HUS) in humans (Bell, 2002). It is the prototype of the enterohemorrhagic $E$. coli (EHEC) class, all of which produce Shiga toxin (Stx) and cause attaching-effacing (A/E) lesions (Law, 2000). In the United States, ground beef is the most common vehicle associated with food-borne outbreaks of $E$. coli O157:H7 ([Caprioli et al., 2005] and [Bar- low et al., 2006]). Cattle are an asymptomatic reservoir of this microorganism; their fecal material is an important source of food and water contamination, and means of spread to humans through direct contact (Renter and Sargeant, 2002).

E. coli O157:H7 expresses an outer membrane protein known as intimin (Eae) and several type III secreted proteins that are involved in the induction of $\mathrm{A} / \mathrm{E}$ lesions in the intestinal epithelium. Some of the more well-characterized type III secreted proteins include the translocated intimin receptor (Tir) and the 
E. coli-secreted proteins [Esp] A and B (Hartland et al., 2000). Proteins involved in the induction of $\mathrm{A} / \mathrm{E}$ lesions are encoded by genes on a chromosomal pathogenicity island known as the locus of enterocyte effacement (LEE) (Frankel et al., 1998). Tir, EspB and other LEE-encoded type III secreted effector proteins are delivered into the host cell through a transiently produced filamentous translocation tube (Nougayrede et al., 2003), which consists of an assembly of EspA subunits (Frankel et al., 1998). These effectors cause a series of cytoskeletal alterations resulting in effacement of the microvilli and pedestal formation at the site of bacterial attachment (Roe et al., 2003). Tir, which has become integrated into the host cell membrane, is bound to intimin, and this event mediates intimate attachment of the bacterium to the host cell (DeVinney et al., 1999).

Intimate attachment of bacteria to mucosal epithelial cells significantly enhances intestinal colonization in cattle and other species. The induction of $\mathrm{A} / \mathrm{E}$ lesions in colonic and rectal (Baehler and Moxley, 2000) and ileal (Phillips et al., 2000) epithelial cells of adult cattle by $E$. coli O157:H7 was first demonstrated using mucosal explants (in vitro organ cultures). Later, these lesions were demonstrated in vivo in adult cattle with the further identification of the terminal rectum as a major site of colonization (Naylor et al., 2005). Further conclusive evidence of the importance of $\mathrm{A} / \mathrm{E}$ lesion formation in colonization has been based on studies with LEE gene deletion mutants. Deletion of eae or the LEE4 operon caused a significant reduction in enteritis and bacterial fecal shedding in experimentally infected calves ([Dean-Nystrom et al., 1998] and [Naylor et al., 2005]). Similarly, deletion of eae resulted in reduced colonization and fecal shedding in experimentally infected yearling cattle (Cornick et al., 2002).

Human patients with HUS caused by E. coli O157: $\mathrm{H} 7$ infection have robust serum antibody responses to Tir ([Li et al., 2000] and [Yoh et al., 2003]). Based on this observation, the hypothesis was raised that type III secreted proteins would be a suitable vaccine target for this pathogen in humans and cattle (Li et al., 2000). Subsequent studies demonstrated that a vaccine prepared from culture supernatant materials enriched with LEE-encoded type III secreted proteins has significant potential as a pre-harvest intervention strategy for E. coli O157:H7 in cattle (Potter et al., 2004). Experimental challenge of calves with an $E$. coli $\mathrm{O} 157: \mathrm{H} 7$ strain containing a deletion of the LEE4 operon also provided proof-of-concept for the utilization of type III secreted proteins as a vaccine strategy (Naylor et al., 2005).
Some studies have not found vaccination to be efficacious. One was a large-scale clinical trial in feedlot cattle which utilized type III secreted proteins as the vaccine antigen. In that study, the proteins were treated with formalin, which may have altered their immunogenicity (van Donkersgoed et al., 2005). In another study, young calves vaccinated with different EHEC antigens developed humoral and salivary IgA responses, but were not protected against intestinal colonization by E. coli O157:H7 following experimental challenge (van Diemen et al., 2007).

Although vaccination of cattle is being actively pursued as an intervention strategy for $E$. coli $\mathrm{O} 157$ : H7, little is known about the bovine immune responses to important bacterial colonization factors resulting from infection. Many of these factors could potentially serve as immunogens, but no information is available about the effects of infection in this regard, which may serve as a priming exposure to the respective antigen. Further, very few studies have been conducted in slaughter-age (adult yearling) cattle, which are the most relevant model, since these animals are the main source of ground beef for human consumption. The primary objective of this study was to determine whether adult cattle develop significant serum and fecal antibody responses to LEE-encoded proteins in response to infection with $E$. coli $\mathrm{O} 157: \mathrm{H} 7$.

\section{MATERIALS AND METHODS}

\subsection{Experimental animals}

Thirty healthy crossbred yearling beef cattle $(\sim 16$ months old, mean weight, $447.7 \pm 86.0 \mathrm{~kg})$ were obtained from the University of Nebraska-Lincoln (UNL) herd at Ithaca, NE. Prior to beginning the study, the cattle were prophylactically treated with topical ivermectin pour-on $(0.5 \mathrm{mg} / \mathrm{kg}$ BW; ProMectin B, Vedco, St. Joseph, MO) and oral sulfamethazine boluses $(350 \mathrm{mg} / \mathrm{kg}$ BW; Sustain III, Bimeda, Inc., Le Sueur, MN). The week immediately prior to inclusion into the study, each animal tested negative for coccidia and nematodes by fecal flotation technique and ectoparasites by clinical examination. Each animal also was negative for Salmonella spp. and $E$. coli $\mathrm{O} 157: \mathrm{H} 7$ in three successive fecal cultures over a 1-week period, using standard enrichment and plating methods ([Smith et al., 2001] and [Smith et al., 2005]), and negative for bovine viral diarrhea virus by antigen capture ELISA conducted on sera. Following the health screen, the cattle $(n=30)$ were tested by indirect ELISA for pre-existing serum IgG and 
IgA antibodies to E. coli O157:H7 intimin, Tir, EspA, EspB and O157 LPS, as described below. Thereafter, six of these animals, chosen at random, were transported to and individually housed in biosafety level (BL)-2 containment rooms. One week prior to use, BL-2 isolation rooms were disinfected by fumigation with paraformaldehyde. Cattle were fed once daily with a nutritionally balanced ration without antibiotics (UNL Beef Feed 51786AAA, Consolidated Nutrition, Omaha, NE) and water was available $a d l i$ bitum. Cattle were acclimated to the rooms and diet prior to inoculation.

\subsection{BL-2 animal isolation rooms}

BL-2 animal isolation rooms had individual floor drains, and floors and walls were washed once daily with water via a high pressure sprayer to minimize repeated challenge from bacteria shed through each animal's own feces. Cross-contamination was prevented by housing one animal per room, and by having animal caretakers and research personnel change personal protective equipment (except respirators) and clothing between rooms. Animal waste was autoclaved in a sewage sterilization plant prior to discharge in the municipal sewage system.

\subsection{Experimental design}

Six healthy yearling beef cattle, individually housed in BL-2 isolation rooms, were orally inoculated once in the feed with $1 \times 10^{9} \mathrm{CFU}$ of $E$. coli $\mathrm{O} 157: \mathrm{H} 7$ (wildtype strain 86-24), and each animal was observed to consume the entire feed sample. EHEC O157:H7 strain 86-24 is $\mathrm{Stx}^{+}$, and was originally isolated from a human patient with bloody diarrhea (Griffin et al., 1988). After inoculation, cattle were examined once daily for clinical signs for the duration of the study. Animal experiments were approved by the UNL Institutional Animal Care and Use Committee, and the UNL Institutional Biosafety Committee.

\subsection{Sample collection and examination}

Samples were collected daily from the centers of fresh fecal pats on the floor for 14 days post-challenge (DPC), and on alternate days for 28 days thereafter to quantify levels of fecal shedding of the inoculum strain. Previous studies have shown the usefulness of copro-antibody quantification for the assessment of intestinal immunoglobulins in calves (Heckert et al., 1991) and other ruminant species (Rehbinder and Hau, 2006). Therefore, fecal samples from the rectum were collected to test for intestinal antibodies, and serum samples from the jugular vein were obtained to assess the humoral response on 0,14, 28 and 42 DPC. Immediately after their collection, serum samples were stored at $-20^{\circ} \mathrm{C}$; whereas fecal samples were suspended 1:5 (w/v) in sodium acetate buffer $(\mathrm{pH} 4.5$, $10 \mathrm{mM}$ ) containing $0.1 \%(\mathrm{w} / \mathrm{v})$ soybean trypsin inhibitor, $5 \mathrm{mM}$ EDTA, $80 \mu \mathrm{g} / \mathrm{ml}$ of gentamicin, $10 \mathrm{IU} / \mathrm{ml}$ penicillin, and $10 \mu \mathrm{g} / \mathrm{ml}$ of streptomycin (Dréau et al., 1995). The mixture was centrifuged once at $2500 \times \mathrm{g}$ for $20 \mathrm{~min}$ to sediment larger particles and once at $15,000 \times g$ for $30 \mathrm{~min}$. Finally, the supernatant was collected and stored at $-20^{\circ} \mathrm{C}$ until the analysis could be performed.

\subsection{Fecal shedding}

Fecal samples were obtained via fresh pats on the floor and immediately processed. Each sample was quantified by direct plating (DP) on SMAC-CT (sorbitol-MacConkey plates containing $0.5 \mu \mathrm{g} / \mathrm{ml}$ cefixime and $2.5 \mathrm{\mu g} / \mathrm{ml}$ potassium tellurite) plates and cultured in enrichment broth $(\mathrm{GN}-\mathrm{VCC}=\mathrm{GN}$ broth containing $8 \mu \mathrm{g} / \mathrm{ml}$ vancomycin, $0.05 \mu \mathrm{g} / \mathrm{ml}$ cefixime and $10 \mu \mathrm{g} /$ $\mathrm{ml}$ cefsulodin) followed by plating on SMAC-CT to detect levels of shedding that were undetectable by DP. For enrichment (E) culture, $10 \mathrm{~g}$ of feces were incubated in $90 \mathrm{ml}$ of GN-VCC for $6 \mathrm{~h}$ at $37^{\circ} \mathrm{C}$. One millilitre of these cultures was subjected to $\mathrm{O} 157 \mathrm{immu}$ nomagnetic separation (IMS, Dynal) and $50 \mu \mathrm{l}$ of the mixture were spread on SMAC-CT plates. Sorbitolnonfermenting colonies were subcultured on MacConkey and Fluorocult (E. Merck) agars. Colonies that fermented lactose but not sorbitol, and lacked B-glucuronidase activity [non-fluorescent on Fluorocult, which contains 4-methylumbelliferyl-b-d glucuronide (MUG)], were further tested for reactions in triple sugar iron, indole and methyl red-Voges-Proskauer media. Indole-positive isolates were subcultured onto blood agar and tested for E. coli $\mathrm{O} 157$ and H7 antigens by latex agglutination test (Remel RIM $^{\circledR}$ E. coli O157:H7 Latex Test). Isolates giving the expected reactions in the aforementioned tests were thus identified as E. coli O157:H7.

\subsection{Antibody response}

Isotype-specific (IgA and IgG) fecal and serum antibody titers were determined by an indirect ELISA using a modification of the procedures previously described by Li et al. (2000). E. coli BL21, a ADE3 lysogen strain containing a pET28 expression vector, kindly provided by Dr. B. Brett Finlay (University of Brit- 
ish Columbia), was the source of E. coli O157:H7 protein antigens. This strain expresses histidine-tagged eae, tir-CesT, espB or espA genes. CesT is the chaperone protein for Tir, which is required for Tir protein stability (Abe et al., 1999). The region of the eae gene cloned into the recombinant intimin construct encodes the 280-carboxyl-terminal amino acids, specific for the $\mathrm{Y}$-intimin subtype. Purified proteins were obtained using commercially available $\mathrm{Ni}^{2+}$ affinity columns (Novagen His-Bind Kit, EMD Biosciences-Merck). The source of E. coli O157 LPS was E. coli O157:H7 strain 86-24, obtained by phenol-water extraction and purified by standard methods (Jann, 1985). Individual wells of microtiter plates were coated with $100 \mu \mathrm{l}$ of Tir (100 ng), intimin (180 ng), EspA (160 ng), EspB (240 ng) (Li et al., 2000), or O157 LPS (150 ng) in a $0.1 \mathrm{M}$ carbonate buffer (pH 9.6), and incubated overnight at $4{ }^{\circ} \mathrm{C}$. After two washes with PBS, wells were blocked with $1 \% \mathrm{BSA}$, heat-treated at $60^{\circ} \mathrm{C}$, in carbonate buffer. Serum samples were serial twofold diluted in PBS and tested at a starting dilution of 1:100 for IgG or 1:20 for IgA. Fecal samples were also serially diluted in PBS, but the initial dilution tested for both IgG and IgA antibodies was the undiluted processed sample (1:5 in sodium acetate buffer). Plates were incubated for $2 \mathrm{~h}$ at $37^{\circ} \mathrm{C}$, washed and blocked, as previously described (Li et al., 2000). One hundred microlitre of a 1:10,000 PBS dilution of horseradish peroxidase-conjugated goat anti-bovine $\operatorname{IgG}(\mathrm{H}+\mathrm{L}$, affinity purified; Jackson Immunoresearch Laboratories) or 1:5000 PBS dilution of horseradish peroxidase-conjugated rabbit anti-bovine IgA (Bethyl Laboratories, Inc.) was added to each well. Plates were incubated for $1 \mathrm{~h}$ at $37^{\circ} \mathrm{C}$, and washed three times with PBS. Orthophenylenediamine plus hydrogen peroxide was used as the substrate for the reaction. ELISAs were read at a wavelength of $490 \mathrm{~nm}$. Three duplicate determinations were performed for each sample. The antibody titer was the highest dilution having an absorbance (mean $-2 \geq$ S.D.) greater than the negative control (mean + S.D.), which included all reagents except the serum.

\subsection{Statistical analysis}

The level and length of fecal shedding were determined. The mean magnitude and duration of fecal shedding were estimated for the first 14 DPC. After $14 \mathrm{DPC}$, shedding was evaluated on alternate days for 28 days. Two means, each calculated from seven observation points over a 14-day sampling period were determined. The mean magnitude of fecal shedding was the geometric mean (GM) expressed as $\log _{10}$ CFU/g (wet weight) of feces. The mean duration of fecal shedding based on DP or E-IMS, expressed as the percent of days in which E. coli $\mathrm{O} 157: \mathrm{H} 7$ was detected was determined. GM antibody titers were calculated from the highest dilution of each serum sample in which a detectable immune response was determined ([Li et al., 2000] and [Potter et al., 2004]). To determine the statistical distribution of the antibody titers, a normality test was performed by the UNIVARIATE procedure of SAS (1999), using the Shapiro-Wilks $W$ statistic. Because antibody titers were not normally distributed, they were analyzed by the non-parametric Kruskal-Wallis test, followed by the Tukey-Kramer test for comparison of means (Dowdy and Wearden, 1991) by SAS (1999). The association between fecal shedding and serum IgG responses (pre-existing or post-challenge titers) was assessed by Spearman's correlation analysis (Proc CORR, SAS, 1999). A significant difference was declared to exist when $P \leq 0.05$. Least squares means (LSM) and the S.E.M. are reported, unless otherwise stated.

\section{RESULTS}

\subsection{Animal health}

All animals were healthy throughout the experiment, including the time period after inoculation with $E$. coli O157:H7. Although cattle actively shed E. coli O157:H7, none developed anorexia or diarrhea, and all maintained or gained weight during the 42 -day experimental period.

\subsection{Pre-inoculation serum IgG and IgA antibody titers}

Pre-inoculation serum antibody titers to 0157 LPS and E. coli O157:H7 intimin, Tir, EspB and EspA were determined by indirect ELISA with individual serum samples taken from 30 healthy adult beef cattle (Figure 1). All animals were IgG-seropositive for all five antigens, with GM IgG titers to EspB and O157 LPS antigens significantly higher $(P<0.05)$ than those detected for Tir, intimin and EspA. Cattle were also seropositive for IgA antibodies to each antigen; however, as expected, the titers were much lower than those detected for serum IgG. The serum IgA titer to EspB was significantly higher $(P<0.05)$ than that to all other antigens. Although the serum IgA titer to Tir was significantly lower $(P<0.05)$ than that to EspA, the former was not significantly different $(P>0.05)$ from IgA titers to O157 LPS or intimin. 


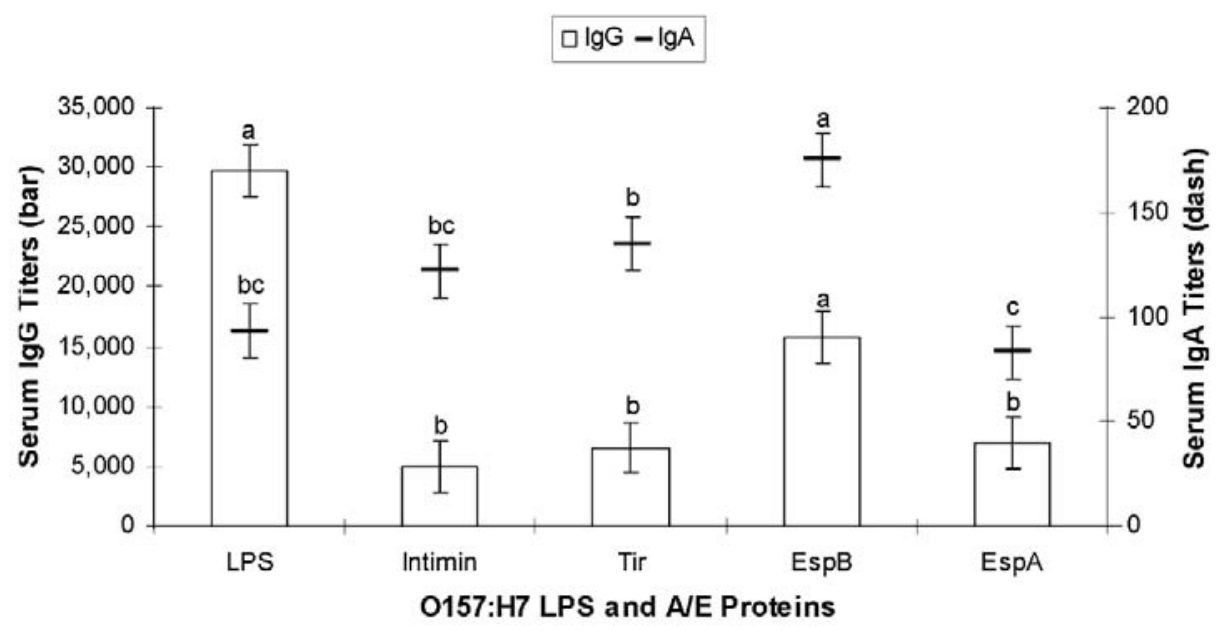

Figure 1. Pre-existing serum IgG and IgA titers to O157 LPS and locus of enterocyte effacement (A/E) proteins in adult cattle. LSM and S.E.M. are presented. Bars (IgG) or dashes (IgA) with the same letters are not significantly different $(P>0.05)$, $n=30$. Samples were tested at a starting dilution of 1:100 for IgG or 1:20 for IgA followed by serial twofold dilutions thereafter. Serological titers are expressed as median values of the highest positive dilution of sera.

\subsection{Magnitude and duration of fecal shedding after experimental inoculation with $E$. coli 0157:H7}

There was a wide variation in the magnitude ( $\left.\log _{10} \mathrm{CFU} / \mathrm{g}\right)$ and duration (percent of days positive) of fecal shedding among animals. The challenge organism was shed in the feces at relatively high levels (GM, $412 \mathrm{CFU/g}$ ) over the first $14 \mathrm{DPC}$. From 15 to 42 DPC the magnitude of shedding decreased $\sim 98 \%$ compared to 1-14 DPC; however, cattle continued to shed the microorganism at low levels, indicating that they were colonized, and that pre-existing serum antibodies to $\mathrm{O} 157 \mathrm{LPS}$ and A/E proteins did not prevent cattle from intestinal colonization by E. coli $\mathrm{O} 157: \mathrm{H} 7$.

Based on the DP and E-IMS procedures, the percent of positive days (mean \pm S.D.) of detection of E. coli $\mathrm{O} 157: \mathrm{H} 7$ in feces, as a measure of duration of shedding for the first $14 \mathrm{DPC}$, was $57 \pm 23 \%$ and $81 \pm 34 \%$, respectively. Thus, as indicated by the duration of fecal shedding, E-IMS procedure was consistently more sensitive for the recovery of E. coli O157: $\mathrm{H} 7$ from feces than DP culture. As determined by DP, fecal shedding of $E$. coli $\mathrm{O} 157: \mathrm{H} 7$, on the average, became undetectable at $24 \mathrm{DPC}$ (range of 8-42 days), whereas by E-IMS procedure a complete decline in fecal shedding was established at an average of $27 \mathrm{DPC}$ (range of 8-42 days).

\subsection{Serum and fecal antibody titers following experimental inoculation with $E$. coli $\mathrm{O} 157: \mathrm{H7}$}

Serum and fecal antibody titers to O157 LPS and $E$. coli O157:H7 intimin, EspA, EspB and Tir were deter- mined at $0,14,28$ and $42 \mathrm{DPC}$, and compared with the magnitude of fecal shedding in orally inoculated cattle. There was no relationship between pre-existing titer to any antigen and the level of shedding after inoculation $(P>0.4$; Figure 2$)$. However, infection resulted in an increase in the serum IgG titers to LEE-encoded proteins above that of the pre-inoculation levels (Figure 3). Coincident with the highest level of fecal shedding at 14 DPC, the GM titers to intimin, Tir and EspB were significantly increased $(P<0.05)$, whereas a significant increase $(P<0.05)$ in the anti-EspA serum response was detected later, at $28 \mathrm{DPC}$. At $14 \mathrm{DPC}$, cattle also had a 1.7 -fold increase in their serum IgG titers to O157 LPS; however, this difference was not significant $(P>0.05)$. By $42 \mathrm{DPC}$, the titers to all antigens, except EspB, were on the decline following the low level of fecal shedding. The serum IgG titers to Tir, intimin and O157 LPS ( $r=0.98, P<0.05$ ), but not EspA or EspB were highly correlated with the level of fecal shedding. Although not statistically significant $(P>0.05)$, serum IgA titers to O157 LPS increased, whereas those to intimin, EspB and Tir decreased by 14 DPC (Figure 4). Pre- and post-inoculation fecal IgG and IgA antibodies to LEE-encoded proteins and O157 LPS were not detected $(<1: 5)$.

\section{DISCUSSION}

The major finding of this study was that adult cattle developed a significant serum IgG antibody response to E. coli O157:H7 LEE-encoded proteins (Tir, EspA, $\mathrm{EspB}$ and Tir) following infection. At the inoculum 

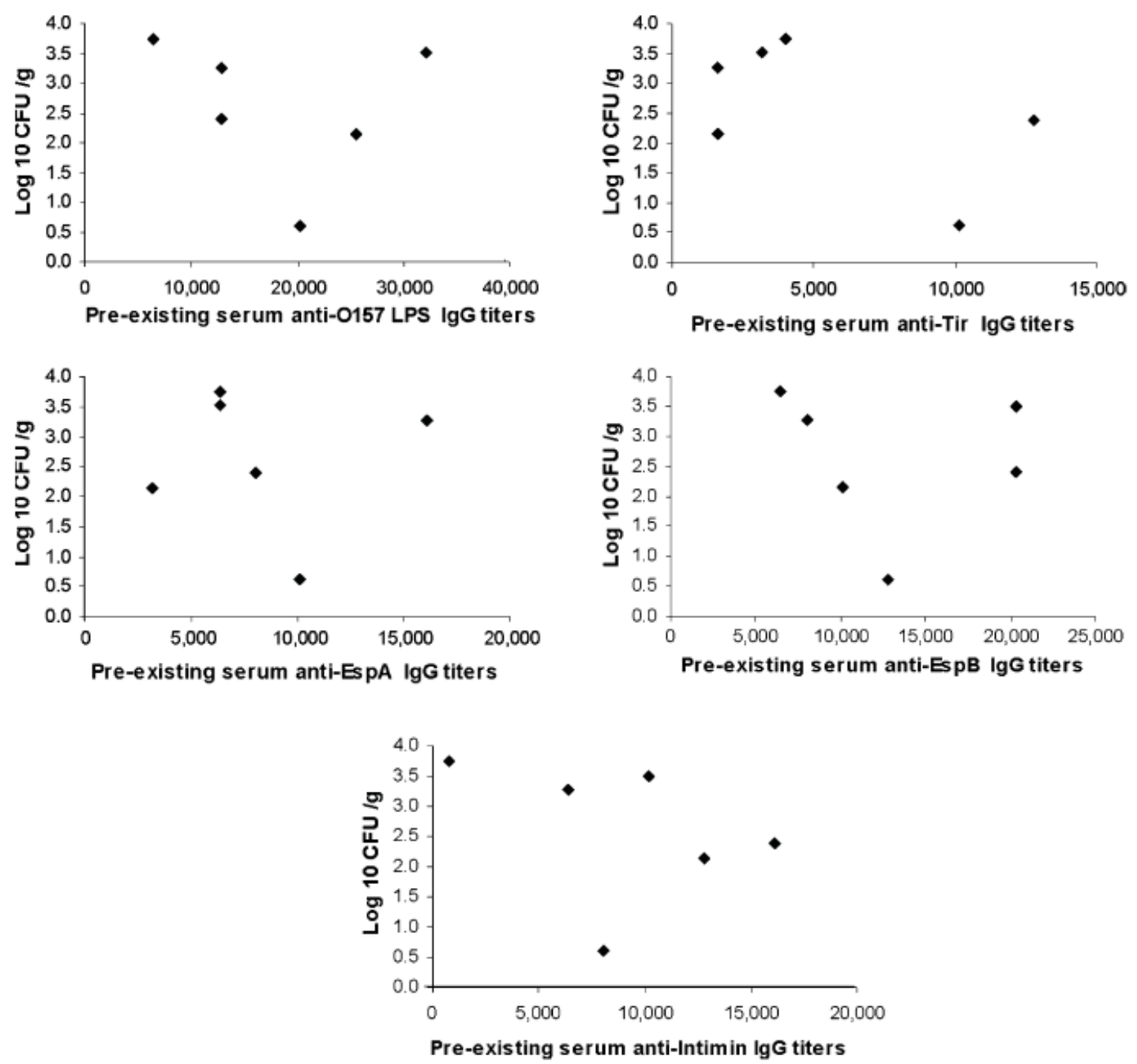

Figure 2. Influence of pre-existing serum IgG titers to O157 LPS and locus of enterocyte effacement (A/E) proteins on Escherichia coli $\mathrm{O} 157: \mathrm{H} 7$ fecal shedding in orally inoculated adult cattle $(n=6)$. Serological titers are the highest positive dilution of sera. Fecal shedding is the mean of 14 days. The correlation between these two variables was not statistically significant $(P>0.4)$.

level we used $\left(1 \times 10^{9} \mathrm{CFU}\right)$, we found that the serum IgG responses of cattle to O157 LPS, intimin, EspA, and Tir were short-lived, whereas that to EspB was greater and more prolonged. It is possible that the responses could have been higher and more pronounced with a higher inoculum level, since Johnson et al. (1996) reported that the serum anti-O157 antibody titers were sustained in adult cattle following an inoculation with $1 \times 10^{10} \mathrm{CFU}$ (Cray and Moon, 1995). To our knowledge, this is the first study to report antibody responses to LEE-encoded proteins in cattle in response to experimental infection. It is of further importance that the study was conducted in adult cattle, which are the major source of ground beef.

We inoculated cattle with a level of $E$. coli O157: $\mathrm{H} 7$ thought to be within the range of a likely natural challenge dose ([Besser et al., 1997], [Besser et al.,
2001] and [Sanderson et al., 1999]). We housed the cattle individually in BL-2 isolation rooms to minimize repeated exposure and prevent cross-contamination from other cattle (Besser et al., 2001), which allowed us to more accurately ascertain the response to a known inoculum level. This approach has an advantage over studying the duration of shedding in natural conditions, since it is difficult in the latter situation to determine the actual inoculum level.

The inoculum dose used in our study was sufficient to induce colonization, as evidenced by the length of fecal shedding, which ranged from 8 to 42 days (mean, 24), and the length of shedding was comparable to that detected in natural infections ([Besser et al., 1997] and [Khaitsa et al., 2003]). Besser et al. (1997) reported that the duration of detected fecal excretion of $E$. coli $\mathrm{O} 157: \mathrm{H} 7$ by naturally infected cat- 


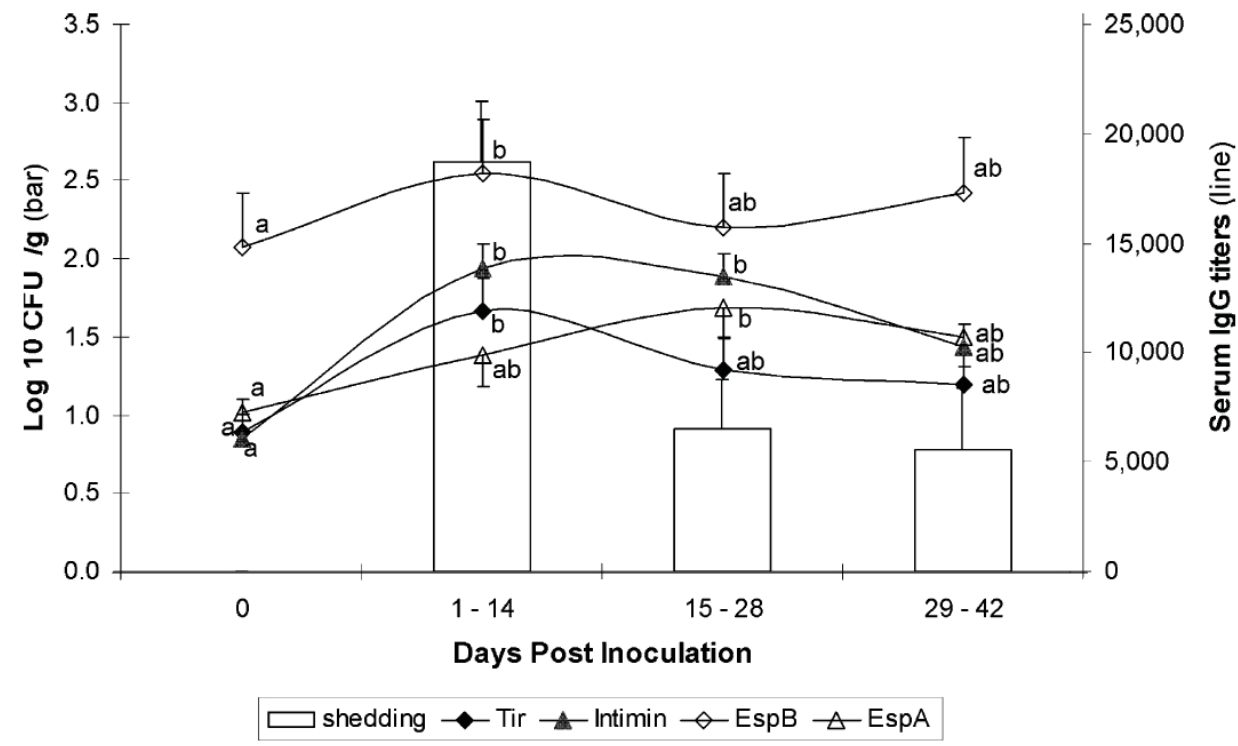

Figure 3. Fecal shedding ( $\square)\left(\log _{10}\right.$ colony-forming units/g) vs. serological IgG immune response to intimin, EspA, EspB and Tir (-) from yearling cattle $(n=6)$ orally inoculated with $E$. coli O157:H7 (Wild type 86-24 strain). At day 0 the pre-existing, field-induced IgG titers are indicated. Serum samples were tested at a starting dilution of 1:100 followed by serial twofold dilutions thereafter. For each immune response, different letters across the $X$-axis indicate statistical difference $(P<0.05)$ among time points (days of bleeding: 0, 14, 28 and 42). LSM and S.E.M. are presented. Serological titers are expressed as median values of the highest positive dilution of sera.

tle was $<1$ month in most cattle tested. Khaitsa et al. (2003) found that the duration of fecal shedding in feedlot cattle ranged from 1 to 4.5 weeks, and peaked during the epidemic phase, which corresponds to times of higher challenge levels.

In our study, since all cattle tested had pre-existing antibodies that had resulted from natural exposure and they shed for 8-42 days after inoculation, we interpret that those responses were insufficient for complete protection. It is possible there was some effect on reduction of shedding; however, we did not find any significant relationship between pre-existing titer to any antigen and shedding. Our group and other researchers have found that young calves ([Naylor et al., 2007] and [Sanderson et al., 1999]) and adult cattle ([Cray and Moon, 1995] and [Khaitsa et al., 2003]) shed less following repeated experimental inoculations, and this suggests that protective immune responses do occur following infection. However, these responses are not completely protective, as evidenced by repeated infections in natural conditions, and the finding that the duration of fecal shedding in these conditions does not differ significantly between the first and second infections or first and third infections (Khaitsa et al., 2003). Other investigators have reported that serum anti-O157 responses were not correlated with elimination of infection or protection against reinfection with the same strain; however, they did not address the responses to anti- gens that have been shown to be important for intestinal colonization ([Johnson et al., 1996] and [Wray et al., 2000]).

The predominance of IgG over IgA antibodies found in this experiment is consistent with the concentrations of these immunoglobulin classes in serum of adult cattle ([Mach and Pahud, 1971] and [Lascelles et al., 1986]). Although cattle are known to mount a significant serum IgG titer to O157 LPS in response to infection with $E$. coli $\mathrm{O} 157: \mathrm{H} 7$ ([Johnson et al., 1996] and [Wray et al., 2000]), we cannot rule out the possibility of serologic cross-reactivity with certain other Gram-negative bacteria as a contributing factor for the pre-existing anti-O157 LPS IgG titers detected in this study ([Chart and Jenkins, 1999], [Laegreid et al., 1998] and [Nielsen et al., 2004]).

A recent study demonstrated that 6-8-week-old calves initially inoculated with an $\mathrm{Stx}^{-}$strain but not $\mathrm{Stx}^{+}$E. coli O157:H7 strain 86-24 developed statistically significant lymphoproliferative responses to heat-killed Stx2 ${ }^{+}$E. coli O157:H7 (Hoffman et al., 2006). In the same study, all calves inoculated with E. coli $\mathrm{O} 157: \mathrm{H} 7$, regardless of Stx production by the respective strain, developed antibodies to O157 LPS. The authors hypothesized that Stxs are immunosuppressive and play a role in promoting STEC colonization in the bovine host, despite the fact that cattle develop humoral immune responses during the course of infection. Although cattle in the present study were 


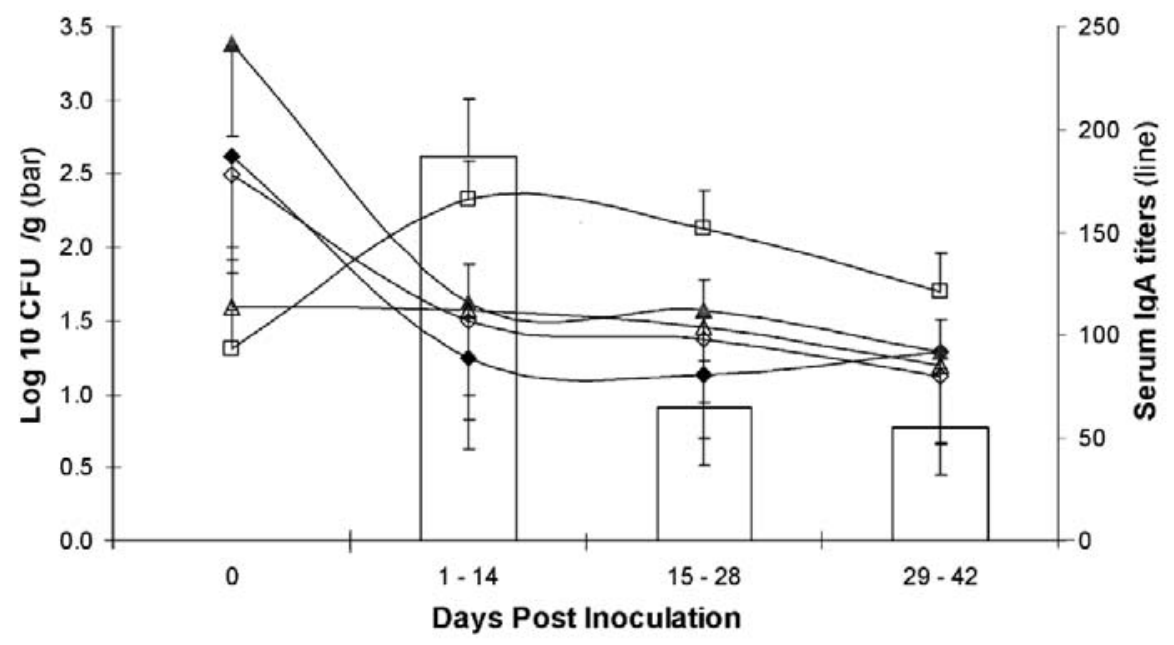

$\square$ shedding $\bullet$ Intimin $\neg$ EspB $\diamond$ Tir $\triangle$ EspA $\square-0157$ LPS

Figure 4. Fecal shedding ( $\square$ ) ( $\log _{10}$ colony-forming units/g) vs. serological IgA immune response to O157 LPS and locus of enterocyte effacement proteins $(-)$ from yearling adult cattle $(n=6)$ orally inoculated with $E$. coli O157:H7 (Wild type 86-24 strain). Data of shedding are the same as those presented in Figure 3. At day 0 the pre-existing, field-induced IgA titers are indicated. Serum samples were tested at a 1:20 starting dilution followed by serial twofold dilutions. Statistical differences were not found among time points (days of bleeding: 0, 14, 28 and 42) for any antigen. LSM and S.E.M. are presented. Serological titers are expressed as median values of the highest positive dilution of sera.

inoculated with the same Stx2 $2^{+}$strain (86-24), we did not address their lymphoproliferative responses.

Overall, we detected a highly significant, positive association between the pattern of fecal shedding and the serum IgG response to Tir, intimin or O157 LPS. Thus, such high positive correlation $(r=0.98)$ may explain the failure of these antigens to induce a longlasting serological IgG response following oral inoculation of cattle. In contrast to the serological IgG titers, the serum IgA titers to Tir, intimin and EspB decreased $(P>0.05)$ after oral challenge. Wray et al. (2000) found that serum IgM but not IgG antibody titers to O157 LPS in calves decreased after experimental infection. These authors did not study the antibody responses to other antigens, nor those of the IgA class. However, a very recent publication has reported that young calves developed serum antibody responses of the IgG and IgA class to $\mathrm{O} 157$ and $\mathrm{H} 7$, and the IgA but not IgG titers decreased after colonization following a repeat challenge (Naylor et al., 2007). Interestingly, in our study, the IgA titers decreased only to factors having a known (Eae, Tir) or highly probable function in colonization (EspB), whereas those to $\mathrm{O} 157$ increased. Hence, as initially proposed by Wray et al. (2000) and extended by the findings of this study and the recent one by Naylor et al. (2007), the decrease in serum IgM and IgA titers soon after challenge may be evidence of their consumption in response to challenge, through binding to E. coli $\mathrm{O} 157: \mathrm{H} 7$ and its secreted products.
Mucosal antibodies to various antigens can be detected in the feces of ruminants ([Heckert et al., 1991] and [Rehbinder and Hau, 2006]), rats (Hau et al., 2001) and humans (Vetvik et al., 1998). Digestive and bacterial proteases can reduce the rate of recovery of antibodies in the feces ([Grewal et al., 2000] and [Vetvik et al., 1998]). However, in the present study, copro-antibodies against $E$. coli $\mathrm{O} 157: \mathrm{H} 7$ antigens were undetectable despite immediate processing and freezer storage of fecal samples, which were attempts to minimize proteolytic degradation. The lack of detection of coproantibodies in our study is similar to the results of Conlan et al. (1999), who reported a very sporadic detection of anti-O157 LPS fecal antibodies in mice orally challenged with E. coli O157:H7. In human patients with enteric disease, the rates of recovery of copro-antibodies are significantly higher in those with active gut inflammation (Ferguson et al., 1995).

In summary, this study has demonstrated that adult cattle respond serologically to E. coli $\mathrm{O} 157: \mathrm{H} 7$ LEE-encoded type III secreted proteins and intimin as a result of infection. In general, protective mucosal immune responses are most effectively induced by mucosal immunization ([Dougan et al., 2000] and [Neutra and Kozlowski, 2006]), but very little information is currently available concerning the bovine mucosal immune responses to E. coli O157:H7. More studies are needed in this regard in order to develop effective preventive and control strategies for $E$. coli O157:H7 in cattle. 


\section{Acknowledgements}

This work was supported by the following funding sources: USDA-CSREES-NRICGP grant \#2001-02966 and USDACSREES Multi-State Research Project NC-1007, "Enteric Diseases of Swine and Cattle: Prevention, Control and Food Safety." The authors thank Mrs. Doreen Bailey and Dr. Marcelo de Lima for technical assistance.

\section{References}

Abe et al., 1999: A. Abe, M. de Grado, R.A. Pfretzner, C. Sanchez-Sanmartin, R. DeVinney, J.L. Puente, N.C. Strymadka and B.B. Finlay, Enteropathogenic Escherichia coli O157: H7 translocated intimin receptor, Tir, requires a specific chaperone for stable secretion, Mol. Microbiol. 33 (1999), pp. 1162-1175.

Baehler and Moxley, 2000: A.A. Baehler and R.A. Moxley, Escherichia coli O157:H7 induces attaching-effacing lesions in large intestinal mucosal explants from adult cattle, FEMS Microbiol. Lett. 185 (2000), pp. 239-242.

Barlow et al., 2006: R.S. Barlow, K.S. Gobius and P.M. Desmarchelier, Shiga toxin-producing Escherichia coli in ground beef and lamb cuts: results of a one-year study, Int. J. Food Microbiol. 15 (2006), pp. 1-5.

Bell, 2002: C. Bell, Approach to the control of enterohemorragic Escherichia coli (EHEC), Ind. J. Food Microbiol. 78 (2002), pp. 197-216.

Besser et al., 1997: T.E. Besser, D.D. Hancock, L.C. Pritchett, E.M. McRae, D.H. Rice and P.L. Tarr, Duration of detection of fecal excretion of Escherichia coli O157:H7 in cattle, J. Infect. Dis. 175 (1997), pp. 726-729.

Besser et al., 2001: T.E. Besser, B.L. Richards, D.H. Rice and D.D. Hancock, Escherichia coli O157:H7 infection of calves: infectious dose and direct contact transmission, Epidemiol. Infect. 127 (2001), pp. 555-560.

Caprioli et al., 2005: A. Caprioli, S. Morabito, H. Brugere and E. Oswald, Enterohaemorrhagic Escherichia coli: emerging issues on virulence and modes of transmission, Vet. Res. 36 (2005), pp. 289-311.

Chart and Jenkins, 1999: H. Chart and C. Jenkins, The serodiagnosis of infections caused by verocytotoxin-producing Escherichia coli, J. Appl. Microbiol. 86 (1999), pp. 731-740.

Conlan et al., 1999: J.W. Conlan, A.D. Cox, R. KuoLee, A. Webb and M.B. Perry, Parenteral immunization with a glycoconjugate vaccine containing the 0157 antigen of Escherichia coli O157:H7 elicits a systemic humoral immune response in mice, but fails to prevent colonization by the pathogen, Can. J. Microbiol. 45 (1999), pp. 279286.

Cornick et al., 2002: N.A. Cornick, S.L. Booher and H.W. Moon, Intimin facilitates colonization by Escherichia coli O157: H7 in adult ruminants, Infect. Immun. 70 (2002), pp. 2704-2707.

Cray and Moon, 1995: W.C. Cray Jr. and H.W. Moon, Experimental infection of calves and adult cattle with Escherichia coli O157:H7, Appl. Environ. Microbiol. 61 (1995), pp. 1586-1590.

Dean-Nystrom et al., 1998: E.A. Dean-Nystrom, B.T. Bosworth, H.W. Moon and A.D. O'Brien, Escherichia coli O157:
$\mathrm{H} 7$ requires intimin for enteropathogenicity in calves, Infect. Immun. 66 (1998), pp. 4560-4563.

DeVinney et al., 1999: R. DeVinney, M. Stein, D. Reinscheid, A. Abe, S. Ruschkowski and B.B. Finlay, Enterohemorrhagic Escherichia coli O157:H7 produces Tir, which is translocated to the host cell membrane but is not tyrosine phosphorylated, Infect. Immun. 67 (1999), pp. 2389-2398.

Dougan et al., 2000: G. Dougan, M. Ghaem-Maghami, D. Pickard, G. Frankel, G. Douce, S. Clare, S. Dunstan and C. Simmons, The immune response to bacterial antigens encountered in vivo at mucosal surfaces, Phil. Trans. Roy. Soc. London, Ser. B 355 (2000), pp. 705-712.

Dowdy and Wearden, 1991: S. Dowdy and S. Wearden, Statistics for Research (2nd ed.), Wiley and Sons, USA (1991) p. 629 .

Dréau et al., 1995: D. Dréau, J.P. Lalles, H. Salmon and R. Toullec, IgM, IgA, IgG1 and IgG2 specific responses in blood and gut secretion of calves fed soyabean products, Vet. Immunol. Immunopathol. 47 (1995), pp. 57-67.

Ferguson et al., 1995: A. Ferguson, K.A. Humphreys and N.M. Croft, Technical report: results of immunological tests on faecal extracts are likely to be extremely misleading, Clin. Exp. Immunol. 99 (1995), pp. 70-75.

Frankel et al., 1998: G. Frankel, A.D. Phillips, I. Rosenshine, G. Dongan, J.B. Kaper and S. Knutton, Enteropathogenic and enterohemorragic Escherichia coli: more subversive elements, Mol. Microbiol. 30 (1998), pp. 911-921.

Grewal et al., 2000: H.M. Grewal, T.H. Karlsen, H. Vetvik, C. Åhrén, H.K. Gjessing, H. Sommerfelt and B. Haneberg, Measurement of specific IgA in faecal extracts and intestinal lavage fluid for monitoring of mucosal immune responses, J. Immunol. Methods 239 (2000), pp. 53-62.

Griffin et al., 1988: P. Griffin, S. Ostroff, R. Tauxe, K. Greene, J. Wells, J. Lewis and P. Blake, Illnesses associated with Escherichia coli O157:H7 infections, Ann. Int. Med. 109 (1988), pp. 705-712.

Hartland et al., 2000: E.L. Hartland, S.J. Danielle, R.M. Delahay, B.C. Neves, T. Wallis, R.K. Shaw, C. Hale, S. Kneelton and G. Frankel, The type III protein translocation system of enteropathogenic Escherichia coli involves EspA-EspB protein interactions, Mol. Microbiol. 35 (2000), pp. 1483-1492.

Hau et al., 2001: J. Hau, E. Andersson and H.E. Carlsson, Development and validation of a sensitive ELISA for quantification of secretory IgA in rat saliva and faeces, Lab. Anim. 35 (2001), pp. 301-306.

Heckert et al., 1991: R.A. Heckert, L.J. Saif, J.P. Mengel and G.W. Myers, Isotype-specific antibody responses to bovine coronavirus structural proteins in serum, feces, and mucosal secretions from experimentally challenge-exposed colostrum-deprived calves, Am. J. Vet. Res. 52 (1991), pp. 692-699.

Hoffman et al., 2006: M.A. Hoffman, C. Menge, T.A. Casey, W. Laegreid, B.T. Bosworth and E.A. Dean-Nystrom, Bovine immune response to shiga-toxigenic Escherichia coli O157: H7, Clin. Vaccine Immunol. 12 (2006), pp. 1322-1327.

Jann, 1985: K. Jann, Isolation and characterization of lipopolysaccharides (O and R antigens) from Escherichia coli. In: M. Sussman, Editor, The Virulence of Escherichia coli. Society for General Microbiology, Academic Press, Orlando, FL (1985), pp. 365-373. 
Johnson et al., 1996: R.P. Johnson, W.C. Cray Jr. and S.T. Johnson, Serum antibody responses of cattle following experimental infection with Escherichia coli O157:H7, Infect. Immun. 64 (1996), pp. 1879-1883.

Khaitsa et al., 2003: M.L. Khaitsa, D.R. Smith, J.A. Stoner, A.M. Parkhurst, S. Hinkley, T.J. Klopfenstein and R.A. Moxley, Incidence, duration, and prevalence of Escherichia coli $\mathrm{O} 157: \mathrm{H} 7$ fecal shedding by feedlot cattle during the finishing period, J. Food Prot. 66 (2003), pp. 1972-1977.

Laegreid et al., 1998: W. Laegreid, M. Hoffman, J. Keen, R. Elder and J. Kwang, Development of a blocking enzymelinked immunosorbent assay for detection of serum antibodies to $\mathrm{O} 157$ antigen of Escherichia coli, Clin. Diagn. Lab. Immunol. 5 (1998), pp. 242-246.

Lascelles et al., 1986: A.K. Lascelles, K.J. Beh, T.K. Mukkur and D.L. Watson, The mucosal immune system with particular reference to ruminant animals. In: W.I. Morrison, Editor, The Ruminant Immune System in Health and Disease, Cambridge University Press (1986), pp. 429-457.

Law, 2000: D. Law, Virulence factors of Escherichia coli O157: H7 and other Shiga toxin-producing Escherichia coli, J. Appl. Microbiol. 88 (2000), pp. 729-745.

Li et al., 2000: Y. Li, E. Frey, A.M.Z. Mackenzie and B.B. Finlay, Human response to human Escherichia coli O157:H7 infection: antibodies to secreted virulence factors, Infect. Immun. 68 (2000), pp. 5090-5095.

Mach and Pahud, 1971: J.P. Mach and J.J. Pahud, Secretory IgA, a major immunoglobulin in most bovine external secretions, J. Immun. 106 (1971), pp. 552-563.

Naylor et al., 2005: S.W. Naylor, A.J. Roe, P. Nart, K. Spears, D.G. Smith, J.C. Low and D.L. Gally, Escherichia coli O157: $\mathrm{H} 7$ forms attaching and effacing lesions at the terminal rectum of cattle and colonization requires the LEE4 operon, Microbiology 151 (2005), pp. 2773-2781.

Naylor et al., 2007: S.W. Naylor, A. Flockhart, P. Nart, D.G.E. Smith, J. Huntley, D.L. Gally and J.C. Low, Shedding of Escherichia coli O157:H7 in calves is reduced by prior colonization with the homologous strain, Appl. Environ. Microbiol. 73 (2007), pp. 3765-3767.

Neutra and Kozlowski, 2006: M.R. Neutra and P.A. Kozlowski, Mucosal vaccines: the promise and the challenge, Nat. Rev. Immunol. 6 (2006), pp. 148-158.

Nielsen et al., 2004: K. Nielsen, P. Smith, J. Widdison, D. Gall, L. Kelly, W. Kelly and P. Nicoletti, Serological relationship between cattle exposed to Brucella abortus, Yersinia enterocolitica 0:9 and Escherichia coli O157:H7, Vet. Microbiol. 100 (2004), pp. 25-30.

Nougayrede et al., 2003: J.P. Nougayrede, P.J. Fernandes and M.S. Donnenberg, Adhesion of enteropathogenic Escherichia coli to host cells, Cell Microbiol. 5 (2003), pp. 359-372.

Phillips et al., 2000: A.D. Phillips, S. Navabpour, S. Hicks, G. Dougan, T. Wallis and G. Frankel, Enterohaemorrhagic Escherichia coli O157:H7 target Peyer's patches in humans and cause attaching/effacing lesions in both human and bovine intestine, Gut 47 (2000), pp. 377-381.

Potter et al., 2004: A.A. Potter, S. Klashinski, Y. Li, E. Frey, H. Townsend, D. Rogan, G. Erickson, S. Hinkley, T. Klopfenstein, R.A. Moxley, D.R. Smith and B.B. Finlay, De- creased shedding of Escherichia coli O157: H7 by cattle following vaccination with type III secreted proteins, Vaccine 22 (2004), pp. 362-369.

Rehbinder and Hau, 2006: C. Rehbinder and J. Hau, Quantification of cortisol, cortisol immunoreactive metabolites, and immunoglobulin A in serum, saliva, urine, and feces for noninvasive assessment of stress in reindeer, Can. J. Vet. Res. 70 (2006), pp. 151-154.

Renter and Sargeant, 2002: D.G. Renter and J.M. Sargeant, Enterohemorrhagic Escherichia coli O157: epidemiology and ecology in bovine production environments, Anim. Health Res. Rev. 3 (2002), pp. 83-94.

Roe et al., 2003: A.J. Roe, D.E.E. Hoey and D.L. Gally, Regulation, secretion and activity of type III-secreted proteins of enterohaemorrhagic Escherichia coli 0157, Biochem. Soc. Trans. 31 (2003), pp. 98-103.

Sanderson et al., 1999: M.W. Sanderson, T.E. Besser, J.M. Gay, C.C. Gay and D.D. Hancock, Fecal Escherichia coli O157:H7 shedding patterns of orally inoculated calves, Vet. Microbiol. 69 (1999), pp. 199-205.

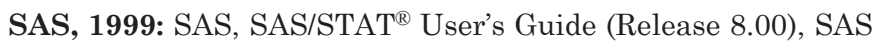
Institute Inc., Cary, NC (1999).

Smith et al., 2001: D.R. Smith, M. Blackford, S. Younts, R. Moxley, J. Grey, L. Hungerford, T. Milton and T. Klopfenstein, Ecological relationships between the prevalence of cattle shedding Escherichia coli $\mathrm{O} 157: \mathrm{H} 7$ and characteristics of the cattle or conditions of the feedlot pen, J. Food Prot. 64 (2001), pp. 1899-1903.

Smith et al., 2005: D.R. Smith, R.A. Moxley, S.L. Clowser, J.D. Folmer, S. Hinkley, G.E. Erickson and T.J. Klopfenstein, Use of rope-devices to describe and explain the feedlot ecology of Escherichia coli O157:H7 by time and place, Foodborne Pathog. Dis. 2 (2005), pp. 50-60.

van Diemen et al., 2007: P.M. van Diemen, F. Dziva, A. AbuMedian, T.S. Wallis, H. van den Bosch, G. Dougan, N. Chanter, G. Frankel and M.P. Stevens, Subunit vaccines based on intimin and Efa-1 polypeptides induce humoral immunity in cattle but do not protect against intestinal colonisation by enterohaemorrhagic Escherichia coli O157:H7 or O26: $\mathrm{H}^{-}$, Vet. Immunol. Immunopathol. 116 (2007), pp. 47-58.

van Donkersgoed et al., 2005: J. van Donkersgoed, D. Hancock, D. Rogan and A.A. Potter, Escherichia coli O157:H7 vaccine field trial in 9 feedlots in Alberta and Saskatchewan, Can. Vet. J. 46 (2005), pp. 724-728.

Vetvik et al., 1998: H. Vetvik, H.M. Grewal, I.L. Haugen, C. Ahren and B. Haneberg, Mucosal antibodies can be measured in air-dried samples of saliva and feces, J. Immunol. Methods 215 (1998), pp. 163-172.

Wray et al., 2000: C. Wray, I.M. McLaren, L.P. Randall and G.R. Pearson, Natural and experimental infection of normal cattle with Escherichia coli O157, Vet. Rec. 147 (2000), pp. 65-68.

Yoh et al., 2003: M. Yoh, Z. Bi, J. Matsuyama, K. Nagayama and T. Honda, Effect of environmental conditions on proteins secreted by enterohemorrhagic Escherichia coli O26:H11, Microbiol. Immunol. 47 (2003), pp. 1-6. 